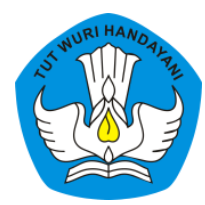

Page: 169-192

\title{
Teknik Showing Berbantuan Multi Media Kreatif untuk Meningkatkan Keterampilan Menulis Teks Narasi
}

\author{
Faiqotur Rosidah \\ Sekolah Menengah Pertama Negeri 3 Peterongan, Jombang, Jawa Timur \\ ${ }^{1}$ Contributor Email: authoremail@example.com
}

Published: Mar 30, 2020

Article Url: http:/ / ojsdikdas.kemdikbud.go.id/index.php/didaktika/article/view/161

\begin{abstract}
This research on the learning technique using Showing assisted by creative multimedia is expected to be able to improve students' narrative text writing skills at SMPN 3 Peterongan. The term Showing refers to two things, the first means show and the second means the acronym of the Survey stage, Hadiirkan Objek (Present Objects), Wujudkan (Realize), Imagine, Narrate, and Gaungkan (Reflect). This research is a learning development study with $4 \mathrm{D}$ model developed by Thiagarajan, et al (1974) which consists of the stages of defining (conducting; analyzing needs), design (designing teaching materials with Showing techniques and validating teaching materials), developing (developing; testing) the use of instructional materials that have been designed), and dessiminate (dissemination; the implementation of learning in the classroom that has been the subject of research). The subjects of this study were four classes, namely classes 7I and 7J and classes 9D and 9E. The total number of research subjects was 129 students. The results of this study are 97\% student are succesful in the group basis, whereas 95\% succesfull in the individually aspect.
\end{abstract}

Keywords: Showing Tecnique; Multimedia; Writing Skills 


\begin{abstract}
Abstrak
Penelitian pembelajaran teknik Showing berbantuan multimedia kreatif ini diharapkan mampu meningkatkan keterampilan menulis teks narasi siswa SMPN 3 Peterongan. Istilah Showing mengacu pada dua hal, yang pertama berarti menunjukkan dan yang kedua berarti akronim dari tahap Survei, Hadirkan Objek, Wujudkan, Imajinasikan, Narasikan, dan Gaungkan. Penelitian ini merupakan penelitian pengembangan pembelajaran dengan model 4D yang dikembangkan Thiagarajan, dkk (1974) yang terdiri atas tahap define (pendefinisian; melakukan analisis kebutuhan), design (perancangan bahan ajar dengan teknik Showing dan validasi bahan ajar), develop (pengembangan; uji coba penggunaan bahan ajar yang telah dirancang), dan dessiminate (pendesiminasian; pelaksanaan pembelajaran di kelas yang telah dijadikan subjek penelitian). Subjek penelitian ini ada empat kelas, yakni kelas 7I dan 7J serta kelas 9D dan 9E Jumlah keseluruhan subjek penelitian 129 siswa. Adapun hasil penelitian ini secara kelompok 97\% tuntas dan secara individual 95\% tuntas.
\end{abstract}

Kata Kunci: Teknik Showing; Multimedia; Keterampilan Menulis

\title{
A. Pendahuluan
}

Era revolosi industri 4.0 ditandai dengan sistem cyber physical, industri virtual, dan internet of things yang berarti konektivitas manusia, mesin, dan data ada di mana-mana (detikinet.com). Demikian halnya dengan tuntutan pendidikan saat ini yang disesuaikan dengan era siswa masa kini, siswa milenial di era digital. Penguasaan terhadap keterampilan abad 21, melek literasi, dan keterampilan berpikir tinggi menjadi bagian dari tuntutan pendidikan yang tak bisa dielakkan lagi. Namun demikian, sebagai guru, acuan pendidikan tetap menyesuaikan dengan tujuan pendidikan dan kurikulum nasional.

Pada pembelajaran Bahasa Indonesia (yang termasuk di dalamnya ada pembelajaran sastra) ada banyak KD yang dapat dikreasikan dengan memanfaatkan media pembelajaran digital. Apalagi ada beberapa KD yang memiliki karakteristik hampir sama. Misalnya saja, jenis teks narasi fiksi seperti fantasi, fabel, cerpen, dan cerita inspiratif.

Selama ini belum ada model, teknik, atau bahan ajar yang dapat digunakan untuk kesemua jenis teks narasi tersebut. Apalagi bahan ajar 
yang memanfaatkan teknologi digital yang menjadi tuntutan zaman dan siswa milenial saat ini. Padahal, secara garis besar struktur teks-teks tersebut hampir sama. Untuk itu, perlu adanya model pengembangan bahan ajar yang menyeluruh khusus untuk teks narasi agar pembelajaran berlangsung efektif, efisien, dan menyenangkan.

Bahan ajar yang dimaksudkan dalam tulisan ini merupakan segala bentuk bahan yang disusun secara sistematis yang memungkinkan siswa dapat belajar secara mandiri dan dirancang sesuai tujuan pembelajaran yang telah ditetapkan. Dengan adanya bahan ajar tersebut, guru akan lebih sistematis dalam membelajarkan kompetensi dasar yang telah dirancang sehingga kompetensi yang diharapkan tercapai secara optimal. Adapun karakteristik bahan ajar adalah self instructional, mampu menjadikan siswa membelajarkan dirinya sendiri dengan bahan ajar yang dikembangkan, self contained, seluruh materi pembelajaran dari satu unit kompetensi atau sub kompetensi yang dipelajari diuraikan secara utuh, stand alone -berdiri sendiri, adaptive -memiliki daya adaptif yang tinggi terhadap perkembangan ilmu dan teknologi-, dan user friendly -setiap intruksi dan paparan informasi yang ditampilkan bersifat membantu dan mudah dipahami pemakainya, (Widodo dan Jasmadi dalam Lestari, 2013: 2).

Selain itu, selama ini pula belum ada bahan ajar yang memadukan beberapa jenis teks narasi tersebut menjadi satu bahan ajar yang memudahkan para guru untuk membelajarkannya. Salas satu peneltian tentang teks narasi pernah dilakukan oleh Betty Suci Tantikasari, dkk dengan judul Keefektivan kemampuan Menulis Karangan Narasi melalui Puzzle Gambar Berseri di SDN Jiken Blora dimuat di jurnal Dinamika Pendidikan Vol XXI No.2 November 2017. Hasilnya 95\% siswa tuntas. Ada lagi penelitian yang dilakukan oleh Asifa Miftakhul Gina, dkk dengan judul Meningkatkan Keterampilan Menulis Karangan Narasi Melalui Model PWIM (Picture Word Inductive Model) Siswa Kelas IV-B SD Negeri Ketib Kecamatan Sumedang Utara Kabupaten Sumedang yang dimuat di jurnal Pena Ilmiah Vol.2 No.1 (2017). Hasilnya, pada siklus ketiga tingkat keberhasilannya mencapai 99\%. 
Kedua penelitian tersebut merujuk pada satu jenis narasi berupa cerpen anak. Adapun penelitian narasi ini merujuk pada beberapa jenis narasi fiksi seperti cerpen, fabel, cerita fantasi, dan cerita inspirasi. Narasi adalah suatu bentuk karangan yang sasaran utamanya adalah tindak tanduk yang dijalin dan dirangkai menjadi sebuah peristiwa yang terjadi dalam suatu kesatuan waktu (Keraf, 2007: 136). Fizona dalam Dalman (2015:105) mengemukakan bahwa karangan narasi adalah suatu bentuk tulisan yang berusaha menciptakan, mengisahkan, dan merangkaikan tindak tanduk perbuatan manusia dalam sebuah peristiwa secara kronologis atau berlangsung dalam suatu kesatuan waktu. Dengan demikian dapat disimpulkan bahwa narasi adalah suatu bentuk karangan yang 1) mengisahkan peristiwa 2) bersifat kronologis, 3) terdapat konflik, dan 4) menggambarkan kepada pembaca bagaimana tokoh mengelola peristiwa atau masalah tersebut.

Selain itu, alasan lain yang mendasari penelitian ini adalah efektivitas dan keterkaitan antar kompetensi dasar antar teks-teks narasinya pun akan menjadi tampak jelas. Alasan-alasan inilah yang melatarbelakangi penelitian bahan ajar untuk teks narasi ini yakni dengan teknik showing berbantuan multimedia kreatif untuk meningkatkan keterampilan menulis teks narasi. Teknik Showing ini diilhami metode CIRC (Cooperative Reading and Composition) dikembangkan oleh Slavin, dan kawan kawan. Slavin (2015) mengemukakan bahwa metode CIRC merupakan salah satu metode pembelajaran kooperatif. Menurutnya pembelajaran kooperatif membantu peserta didik untuk mengembangkan kemampuannya. CIRC merupakan metode yang komprehensif dalam pembelajaran membaca dan menulis secara integratif. Artinya, pembelajaran membaca dan menulis merupakan satu kesatuan yang terintegrasi dilakukan dengan pembelajaran kooperatif. Secara berkelompok peserta didik memahami model teks dan selanjutnya menulis teksnya.

Istilah Showing dalam tulisan ini merujuk pada dua hal: pertama, Showing dalam arti harfiah berasal dari bahasa Inggis yang berarti 
menunjukkan; kedua Showing sebagai akronim langkah-langkah dalam pembelajaran menulis narasi, yakni dimulai dengan Survei, Hadirkan Objek, Wujudkan, Imajinasikan, Naskah Narasi, dan Gaungkan (mencetak menjadi buku kumpulan narasi).

Berdasarkan latar belakang tersebut, rumusan masalah dalam makalah inovasi pembelajaran ini adalah sebagai berikut: 1) Bagaimanakah pelaksanaan teknik Showing berbantuan multimedia kreatif untuk meningkatkan keterampilan menulis teks narasi di SMP Negeri 3 Peterongan?; 2) Bagaimanakah hasil pembelajaran dengan teknik Showing berbantuan multimedia kreatif untuk meningkatkan keterampilan menulis teks narasi di SMP Negeri 3 Peterongan? Dengan demikian, tujuan penelitian inovasi pembelajaran ini adalah sebagai berikut: 1) Mendeskripsikan pelaksanaan teknik Showing berbantuan multimedia kreatif untuk meningkatkan keterampilan menulis teks narasi di SMP Negeri 3 Peterongan; dan 2) Mendeskripsikan hasil pembelajaran dengan teknik Showing berbantuan multimedia kreatif untuk meningkatkan keterampilan menulis teks narasi di SMP Negeri 3 Peterongan.

Hasil penelitian pembelajaran ini diharapkan bisa memberikan manfaat bagi guru, khususnya guru Bahasa Indonesia, agar pembelajaran lebih efektif, kreatif, inovatif, dan menyenangkan. Bagi siswa, penelitian ini diharapkan dapat memberikan motivasi untuk gemar menulis dan dapat meningkatkan keterampilan menulis narasi siswa pada mata pelajaran Bahasa Indonesia khususnya, serta sebagai modal kemahiran atau kecakapan hidup di masa depannya. Keterampilan menulis narasi dapat dijadikan profesi yang menjanjikan di masa depannya.

\section{B. Metode}

Penelitian ini merupakan penelitian pengembangan dalam pembelajaran dengan desain Model 4D yang dikembangkan Thiagarajan, dkk (1974). Model ini terdiri atas define, design, develop, dan dessiminate. 


\section{Define (Pendefinisian}

Pada tahap ini langkah-langkah yang penulis lakukan adalah melakukan analisis kebutuhan. Analisis kebutuhan mencakup analisis karakteristik siswa dan analisis kurikulum. Analisis kurikulum meliputi analisis kompetensi dasar (KD), analisis materi, dan analisis tujuan pembelajaran. Ketiga hal ini merupakan satu kesatuan yang tidak terpisahkan.

Karakteristik siswa di SMP Negeri 3 Peterongan dapat dijabarkan sebagai berikut.

a. Jumlah siswa rata-rata per kelas adalah 32 dengan pembedakan jenis kelamin; ada kelas laki-laki dan ada kelas perempuan (SMPN 3 Peterongan adalah sekolah pesantren sehingga pembagian kelas laki-laki dan perempuan dibedakan);

b. Sebagian besar siswa berdomisili di asrama Darul Ulum $( \pm 85 \%)$. Hal tersebut berdampak pada motivasi dan antusiasme mereka. Terkadang mereka tampak mengantuk dan lelah karena kegiatan di asrama. Oleh karena itu, kreativitas guru dalam mengelola pembelajaran menjadi penentu keberhasilan;

c. Berdasarkan survei awal ketika mereka diminta oleh guru untuk menulis paragraf bebas, sebanyak 25/32 atau $88 \%$ masih belum bagus dalam pemilihan diksi, pengaturan kalimat, penggunaan kata sambung, dan pengembangan ide kreatif. Di samping itu, kegemaran menulis mereka belum cukup baik terbukti ketika ditanya sebagian besar siswa (85\%) mengaku tidak suka menulis.

Penjabaran analisis kurikulum adalah sebagai berikut: a) Pada mata pelajaran bahasa Indonesia SMP kurikulum 2013 untuk materi teks narasi ada empat jenis teks narasi, yakni fantasi, fabel, cerpen, dan cerita inspiratif; b) Secara umum masing-masing jenis teks memiliki dua kompetensi dasar untuk KI 3 dan dua KD untuk KI 4. Bunyi masingmasing kompetensi tersebut adalah mengidentifikasi ciri umum, dan 
menelaah struktur dan unsur kebahasaan teks (KI 3) serta menyimpulkan dan menyajikan teks (KI 4).

Teks fantasi dipelajari di kelas VII semester satu. Teks Fabel di kelas VII semester 2. Teks cerpen kelas IX semester satu dan teks cerita inspiratif di kelas IX semester dua. Adapun tujuan pembelajaran untuk materi teks narasi ini secara umum adalah "siswa dapat menyajikan teks narasi dengan memperhatikan struktur dan unsur kebahasaannya baik secara lisan maupun tulis". Dengan demikian, objek penelitian ini adalah teks narasi fiksi yang mencakup cerita fantasi, teks fabel, teks cerpen, dan teks cerita inspirasi.

Tujuan pembelajaran umum ini dirinci menjadi indikatorindikator pencapaian kompetensi berikut: 1) setelah membaca (survei) kritis beberapa contoh teks narasi, siswa dapat menentukan tema atau ide kreatif yang menjadi dasar penulisan teks narasi dengan kreatif, 2) siswa dapat menjabarkan ide kreatifnya menjadi kerangka karangan dalam bentuk peta konsep dengan objek-objek yang jelas, 3) siswa dapat mengembangkan kerangka karangan menjadi naskah teks narasi yang utuh sesuai dengan struktur dan unsur kebahasaan teks narasi 4) siswa dapat menyajikan hasil karya narasinya secara lisan (presentasi) dan tulis (portofolio/buku kumpulan narasi).

\section{Design (Perancangan)}

Pada tahap ini kegiatan yang dilakukan peneliti adalah merancang pembelajaran sesuai analisis kebutuhan yang telah diidentifikasi. Selanjutnya, peneliti mengembangkan rancangan pembelajaran menjadi draf bahan ajar. Bahan ajar yang dirancang dalam tahap ini masih perlu diterjemahkan agar dapat diaplikasikan.

Rancangan pembelajaran dimulai dari mengembangkan silabus, RPP, bahan ajar, media, dan penilaian dengan kompetensi dasar menyajikan teks narasi. Karena narasi yang ada di mata pelajaran bahasa 
Indonesia kurikulum 2013 ada empat macam teks, perancangan bahan ajar dalam inovasi ini bersifat umum. Bahan ajar yang dirancang dalam karya inovasi ini berupa media cetak berupa buku kerja siswa yang didesain sesuai dengan teknik yang dikembangkan dalam karya inovasi ini, yakni Teknik Showing (Berbantuan Multimedia Kreatif) untuk Meningkatkan Keterampilan Menulis Teks Narasi Siswa. Langkahlangkah pembelajaran dan tugas siswa terencana dalam BKS ini. Selain itu, BKS ini juga memuat manual book atau petunjuk pemanfaatan media pembelajaran. Dengan BKS ini diharapkan siswa dapat dengan mudah meningkatkan kompetensinya khususnya dalam menulis teks narasi.

Perencanaan media pembelajaran (selain BKS), juga memanfaatkan media digital yang saat ini tersedia di layanan internet. Peneliti memanfaatkan tiga aplikasi yakni Sparkol Video Srcibe (SVC), Power Point Presentatation (PPT), dan Powtoon (PT). Ketiga aplikasi ini mudah diakses dan diunduh di internet. Rancangan penilaian keterampilan menulis teks narasi yang berupa portofolio hasil karya siswa dilakukan dengan menggunakan rubrik penilaian keterampilan menulis teks narasi. Adapun standar ketuntasan minimalnya sesuai dengan SKM/KKM yang ditetapkan sekolah yakni 80. Adapun rubrik penilaiannya sesuai tabel 3.1 berikut ini.

Tabel 3.1. Rubrik Penilaian Menulis Teks Narasi

\begin{tabular}{|r|l|r|c|}
\hline \multicolumn{1}{|c|}{ No } & \multicolumn{1}{|c|}{ Aspek } & $\begin{array}{c}\text { Ada/ } \\
\text { Tidak }\end{array}$ & Ket \\
\hline 1. & \multicolumn{1}{|c|}{$\begin{array}{l}\text { Pemilihan Tema } \\
\text { aktual dan secara psikologis sesuai dengan usia }\end{array}$} & & \\
\hline b. & Satu tema dan koherensif & & \\
\hline c. & Tidak menyinggung suku, ras, dan agama & & \\
\hline d. & Mengandung nilai moral & & \\
\hline
\end{tabular}




\begin{tabular}{|r|l|c|c|}
\hline \multicolumn{1}{|c|}{ No } & \multicolumn{1}{|c|}{ Aspek } & $\begin{array}{c}\text { Ada/ } \\
\text { Tidak }\end{array}$ & Ket \\
\hline 2. & \multicolumn{1}{|c|}{$\begin{array}{l}\text { Pengaluran/ struktur teks } \\
\text { a. }\end{array}$} & & \\
\hline b. & Merdapat 4 struktur teks & & \\
\hline c. & Menyampaikan lebih dari satu konflik & & \\
\hline d. & Membuat akhiran mengejutkan & & \\
\hline e. & Memberikan gambaran peristiwa dengan jelas (showing) & & \\
\hline f. & Memberi pesan yang mudah diterima & & \\
\hline 3. & Kreativitas Ide & & \\
\hline a. & Ide diekspresikan dengan jelas & Peristiwa dikembangkan secara rinci dan unik & \\
\hline c. & Pilihan kata menarik & & \\
\hline d. & Dialog menarik/tidak monoton & & \\
\hline 3. & Kebahasaan & & \\
\hline a. & Menggunakan diksi bahasa Indonesia semiformal/ formal & & \\
\hline b. & Menggunakan bahasa yang komunikatif & & \\
\hline c. & $\begin{array}{l}\text { Menggunakan kalimat emotif/empati/simpati (khusus } \\
\text { narasi inspiratif) }\end{array}$ & & \\
\hline d. & Menggunakan kalimat yang jelas dan runtut & & \\
\hline 4. & Penggunaan ejaan dan tanda baca & \\
\hline a. & Tidak ada kesalahan atau kesalahan ejaan $\leq 5$ & \\
\hline b. & Tidak ada kesalahan atau kesalahan tanda baca $\leq 5$ & \\
\hline & & & \\
\hline
\end{tabular}

Keterangan : Aspek ada, skor 5, tidak ada skor 2

Nilai Akhir

Nilai $=\underline{\text { Jumlah skor perolehan }} \times 100 \%$ Jumlah skor maksimal

\section{Develop (Pengembangan)}

Setelah rancangan bahan pembelajaran dibuat, tahap selanjutnya adalah pengembangan. Rancangan bahan ajar yang telah dibuat pada tahap design tersebut menjadi prototype. Prototype atau model pengembangan bahan ajar sebagai karya inovasi yang dikembangkan dalam pembelajaran ini. Prototype ini dikonsultasikan pada ahli pembelajaran. Dalam hal ini penulis berkolaborasi dengan JP, M.Hum (V1), dosen JPBSI UNESA dan Dr. EED, M.Pd (V2), dosen STKIP PGRI 
Jombang. Selain itu, peneliti juga berkolaborasi dengan dua teman sejawat, guru bahasa Indonesia di SMP Negeri 3 Peterongan. Rancangan tabel validasi adalah sebagai berikut.

Tabel 3.2. Validasi terhadap Model Pengembangan Pembelajaran

\begin{tabular}{|c|l|l|l|l|l|l|}
\hline No & \multicolumn{1}{|c|}{ Aspek } & $\begin{array}{c}\text { Validator } \\
1\end{array}$ & $\begin{array}{c}\text { Validator } \\
2\end{array}$ & $\begin{array}{c}\text { Validator } \\
3\end{array}$ & $\begin{array}{c}\text { Validator } \\
4\end{array}$ & $\begin{array}{c}\text { Rata- } \\
\text { Rata }\end{array}$ \\
\hline 1. & Silabus & & & & & \\
\hline 2. & RPP & & & & & \\
\hline 4. & Bahan Ajar (BKS) & & & & & \\
\hline & $\begin{array}{l}\text { Media Pembelajaran } \\
\text { 1) Media 1 (VS) }\end{array}$ & & & & & \\
& $\begin{array}{l}\text { 2) Media 2 (PPT) } \\
\text { 3) Media 3 (PT) }\end{array}$ & & & & & \\
\hline 6. & Teknik Pembelajaran & & & & & \\
\hline 7. & Penilaian & & & & & \\
\hline
\end{tabular}

Keterangan

4 = Sangat bagus, sangat layak digunakan

$3=$ Bagus, layak digunakan

$2=$ Cukup, perlu direvisi

$1=$ Kurang, tidak layak digunakan

Pada tahap uji coba yang dilaksanakan pada minggu ketiga Agustus 2018 didapatkan hasil sebagai berikut. Pertama, berdasarkan data hasil observasi aktivitas sebagian besar siswa aktif selama pembelajaran (30 dari 33 siswa). Kedua, respon terhadap bahan pembelajarannya pun $90 \%$ baik, hanya saja menurut mereka waktu yang disedian masih kurang. Hal ini dikarenakan peneliti menggunakan alokasi waktu lebih pendek dari rancangan yang dibuat. Hasil uji coba di kelas ini pun baik, berdasarkan nilai yang diperoleh peserta didik secara kelompok tuntas secara keseluruhan dan secara individu $88 \%$ telah tuntas. Kesimpulannya adalah model pengembangan pembelajaran ini dapat digunakan. 


\section{Desseminate (Diseminasi)}

Diseminasi merupakan tahap akhir pengembangan. Diseminasi direncakan dilaksanakan pada dua hal. Pertama, disemanisai yang mengacu pada pelaksanaan penelitian pengembangan bahan ajar ini dan kedua, diseminasi hasil penelitian untuk para guru bahasa Indonesia di lingkup MGMP Bahasa Indonesia di tingkat SMP.

Diseminasi pertama pada tahap pengembangan teknik showing (Berbantuan Multimedia Kreatif) untuk Meningkatkan Keterampilan Teks Narasi dimanfaatkan di kelas yang menjadi subjek penelitian. Kelas yang dimaksud adalah Kelas VII-I, J dan IX-D, E tahun ajaran 2018/2019. Masing-masing Kelas VII berjumlah 33 siswa, dan kelas IX sebanyak 32 siswi. Dengan demikian subjek penelitian ini empat kelas dengan jumlah siswa keseluruhan 129.

Tahapan-tahapan rancangan penelitian pengembangan model pembelajaran Teknik Showing (Berbantuan Multimedia Kreatif) untuk Meningkatkan Keterampilan Teks Narasi tampak pada diagram 1 berikut ini.

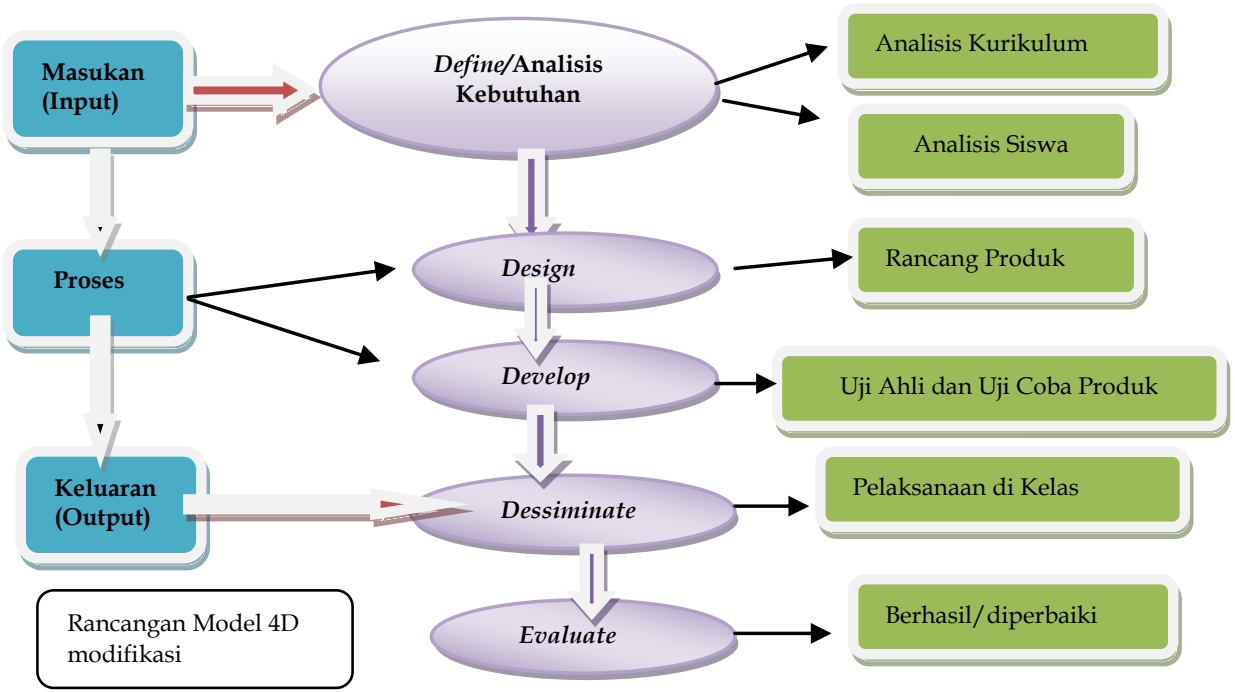

Diagram 1: Tahapan Penelitian Teknik Showing (Berbantuan Multimedia Kreatif) untuk Meningkatkan Keterampilan Teks Narasi 


\section{Hasil dan Pembahasan}

\section{Hasil Validasi Perangkat Pembelajaran}

Berdasarkan hasil validasi ahli dan teman sejawat didapatkan data sesuai tabel 4.1 berikut.

Tabel 4.1. Hasil Validasi terhadap Model Pengembangan Pembelajaran

\begin{tabular}{|c|c|c|c|c|c|c|}
\hline No & Aspek & $\begin{array}{c}\text { Validator } \\
1\end{array}$ & $\begin{array}{c}\text { Validator } \\
2\end{array}$ & $\begin{array}{c}\text { Validator } \\
3\end{array}$ & $\begin{array}{c}\text { Validator } \\
4\end{array}$ & $\begin{array}{l}\text { Rata- } \\
\text { Rata }\end{array}$ \\
\hline 1. & Silabus & 3 & 3 & 4 & 4 & 3,5 \\
\hline 2. & RPP & 3 & 3 & 4 & 4 & 3,5 \\
\hline 4. & Bahan Ajar (BKS) & 4 & 3 & 4 & 4 & 3,75 \\
\hline 5. & \begin{tabular}{ll}
\multicolumn{3}{l}{ Media Pembelajaran } \\
1) & Media 1 (VS) \\
2) & Media $2(\mathrm{PPT})$ \\
3) & Media $3(\mathrm{PT})$
\end{tabular} & $\begin{array}{l}2 \\
4 \\
3\end{array}$ & $\begin{array}{l}3 \\
3 \\
4\end{array}$ & $\begin{array}{l}3 \\
4 \\
4\end{array}$ & $\begin{array}{l}4 \\
3 \\
3\end{array}$ & $\begin{array}{c}3 \\
3,5 \\
3,5\end{array}$ \\
\hline 6. & Teknik Pembelajaran & 3 & 4 & 4 & 3 & 3,5 \\
\hline 7. & Penilaian & 4 & 3 & 4 & 3 & 3,5 \\
\hline
\end{tabular}

Keterangan

4 = Sangat bagus, sangat layak digunakan

3 = Bagus, layak digunakan

2 = Cukup, perlu direvisi

$1=$ Kurang, tidak layak digunakan

Berdasarkan tabel tersebut, perangkat pembelajaran yang telah dirancang peneliti layak digunakan.

\section{Aplikasi Praktis dalam Pembelajaran}

Pelaksanaan pembelajaran dengan Teknik Showing Berbantuan Multimedia Kreatif untuk Meningkatkan Keterampilan Menulis Narasi dimulai pada Oktober minggu pertama dan kedua di kelas VII-J dan IX-E. Untuk semester ganjil teks narasi kelas tujuh adalah teks fantasi, dan kelas sembilan teks cerpen. Pada kelas VII-J pembelajaran teks fantasi Pembelajaran ini dilakukan melalui dua kegiatan, yakni menyajikan teks fantasi kelompok dan menyajikan teks fantasi mandiri. Prosedur 
keduanya hampir sama hanya beda tagihan. Jika menyajikan teks fantasi kelompok tagihannya adalah karya kreatif kelompok. Adapun pada menyajikan teks fantasi mandiri tagihannya adalah karya kreatif individu.

\section{Menulis Teks (Narasi) (8 x pertemuan, @ $2 \mathrm{JP})$}

Sesuai dengan teknik SHOWING yang dikembangkan penulis, setelah apersepsi peserta didik melakukan kegiatan survei. Survei berarti membaca beberapa contoh teks fantasi sebagai model teks. Teks narasi yang dibaca siswa minimal ada tiga model teks yang berbeda. Selesai membaca mereka mengelompok (pengelompokan dengan mengambil undian warna) untuk membahas unsur-unsur fantasi, struktur, dan ciri kebahasaannya. Alokasi waktu untuk kegiatan ini adalah satu kali pertemuan atau dua jam pelajaran (@40 menit). Kegiatan ini mengembangkan keterampilan collaboration dan communication pada diri siswa.

Kegiatan mengidentifikasi dan menelaah teks tahap pertama selesai. Kegiatan berikutnya, mereka menukar hasil dan mengidentifikasi perbedaan temuan. Dua jam pelajaran berlalu pada tahap ini. Selanjutnya, mereka melakukan survei kedua. Survei kedua mereka diajak ke perpustakaan untuk mencari buku-buku teks narasi dan menandai cirinya dengan menuliskan hasilnya di lembar kerja. Hasil masing-masing kelompok ditukar dan ditanggapi. Dalam kegiatan ini guru dibantu kolaborator dan petugas perpustakaan untuk menyediakan bahan bacaannya. Keterampilan yang dikembangkan pada tahap ini adalah critical thinking.

Kata kunci yang sudah mereka dapatkan tersebut selanjutnya digunakan pada konteks yang lain. Masing-masing anak membuat kalimat berdasarkan kata kunci tersebut. Kalimat yang telah dibuat ditukar dengan teman dalam kelompoknya untuk dikomunikasikan dan ditanggapi (comunication and critical thinking).

Survei ketiga dilakukan dengan menyaksikan tayangan serta mengikuti instruksi multimedia kreatif PPT, SVS, atau Powtoon (2jp) yang disiapkan guru sebagai fasilitator. Tujuan pada survey ketiga ini agar siswa mampu 
mengidentifikasi ciri umum teks fantasi dan mampu menyimpulkan isi teks fantasi sebagai pengetahuan dan keterampilan prasyarat sebelum mereka membuat teks fantasi. Kegiatan dimulai dengan penayangan multimedia. Siswa mengidentifikasi tema cerita, tokoh, dan ciri umum teks. Kegiatan berikutnya mereka menganalisis tiga teks narasi sampai dengan mempresentasikan hasil.

Pada tahap Hadirkan Objek siswa merencanakan projek pembuatan cerita narasinya. Dimulai dengan penentuan objek atau tema yang akan dibuat sampai menentukan frame atau kerangka ceritanya. Dalam kegiatan ini siswa memanfaatkan metakognitifnya ketika melakukan pembelajaran pada tahap survei.

Wujudkan Objek, artinya siswa berlatih menghidupkan objek. Pada tahap ini siswa berlatih membuat kalimat atau paragraf showing. Selama ini kelemahan siswa dalam menulis narasi adalah kesulitan dalam mengungkapkan sesuatu secara detail dan jelas. Melalui contoh-contoh dan latihan-latihan membuat kalimat showing ini diharapkan kualitas menulis siswa terasah dengan baik. Panduan yang digunakan siswa berupa buku kerja siswa (BKS teknik Showing).

Setelah berlatih membuat kalimat showing, siswa melangkah pada tahapan selanjutnya yakni Imajinasikan. Kegiatan yang mereka lakukan adalah melanjutkan kerangka narasinya dengan memanfaatkan seluruh imajinasi, potensi, dan menghidupkannya melalui panca indranya. Siswa mendeteksi bagian-bagian mana yang perlu dihidupkan melalui showing dan bagian-bagian mana yang tidak perlu di-showing-kan. Kegiatankegiatan tersebut merupakan pengembangan keterampilan berkreativitas atau creativity and innovation.

Pada tahap Naskah narasi, siswa diharapkan menulis teks narasinya dengan lengkap. Awalnya, kegiatan ini mereka lakukan secara berkelompok dan hasil kerja kelompok dipajang dan ditanggapi oleh kelompok lain (Gaungkan). Guru sebagai pembimbing sekaligus fasilitator memberikan reward dan penguatan pada siswa agar mereka lebih termotivasi untuk menyelesaikan projek cerita narasi individunya. 
Setelah tugas kelompok selesai, siswa menulis teks narasi individunya. Tugas mandiri ini lebiha banyak mereka lakukan di luar jam pembelajaran. Siswa dapat mengonsultasikan tugasnya ketika jam pelajaran atau di luar jam pelajaran di waktu-waktu yang tidak mengganggu pembelajaran kelas lain.

Alokasi waktu mulai tahap Hadirkan Objek sampai Gaungkan adalah lima kali pertemuan atau sepuluh jam pelajaran. Akan tetapi, siswa juga membutuhkan banyak waktu di luar jam pelajaran untuk menyelesaikan tugasnya dan hasil akhir karya mereka pun dibukukan (ISBN). Dengan demikian, pengembangan keterampilan 4C (communication, collaboration, critical thinking, and creativity) sebagai syarat penguasaan keterampilan di abad XXI sudah terimplimentasikan dalam pembelajaran ini.

\section{Data Hasil Aplikasi Praktis}

Berdasarkan rubrik penilaian didapatkan data hasil pembelajaran menulis narasi dengan teknik Showing adalah sebagai berikut.

Tabel 4.2 Data Hasil Penilaian Kelompok

\begin{tabular}{|c|l|l|l|l|}
\hline No & \multicolumn{1}{|c|}{ Kelas } & \multicolumn{1}{|c|}{ Jenis Narasi } & \multicolumn{1}{|c|}{ Hasil } & Keterangan \\
\hline 1. & $7 \mathrm{~J}$ & Teks Fantasi & $\begin{array}{l}7 \text { kelompok } \\
\text { tuntas }\end{array}$ & $\begin{array}{l}\text { Jumlah } \\
\text { kelompok 7 }\end{array}$ \\
\hline 2. & $7 \mathrm{I}$ & $\begin{array}{l}\text { Teks } \\
\text { Fabel/Legenda }\end{array}$ & $\begin{array}{l}8 \text { kelompok } \\
\text { tuntas }\end{array}$ & $\begin{array}{l}\text { Jumlah } \\
\text { kelompok 8 }\end{array}$ \\
\hline 3. & IX-E & Teks Cerpen & $\begin{array}{l}8 \text { kelompok } \\
\text { tuntas }\end{array}$ & $\begin{array}{l}\text { Jumlah } \\
\text { kelompok 8 }\end{array}$ \\
\hline 4. & IX-D & $\begin{array}{l}\text { Teks Cerita } \\
\text { Inspiratif }\end{array}$ & $\begin{array}{l}7 \text { dari 8 kelompok } \\
\text { tuntas }\end{array}$ & $\begin{array}{l}\text { 1 kelompok } \\
\text { belum tuntas }\end{array}$ \\
\hline
\end{tabular}

Tabel 4.3 Data Hasil Penilaian Mandiri 


\begin{tabular}{|c|l|l|l|l|}
\hline No & \multicolumn{1}{|c|}{ Kelas } & \multicolumn{1}{|c|}{ Jenis Narasi } & \multicolumn{1}{|c|}{ Hasil } & \multicolumn{1}{|c|}{ Keterangan } \\
\hline 1. & $7 \mathrm{~J}$ & Teks Fantasi & $\begin{array}{l}\text { 31 dari 33 siswa } \\
\text { tuntas }\end{array}$ & $\begin{array}{l}\text { Ada 2 siswa } \\
\text { yang belum } \\
\text { tuntas }\end{array}$ \\
\hline 2. & $7 \mathrm{I}$ & $\begin{array}{l}\text { Teks } \\
\text { Fabel/Legenda }\end{array}$ & $\begin{array}{l}\text { 29 dari 32 siswa } \\
\text { tuntas }\end{array}$ & $\begin{array}{l}\text { Ada 3 siswa } \\
\text { yang belum } \\
\text { tuntas }\end{array}$ \\
\hline 3. & IX-E & Teks Cerpen & 32 siswa tuntas & Jumlah siswa 32 \\
\hline 4. & IX-D & $\begin{array}{l}\text { Teks Cerita } \\
\text { Inspiratif }\end{array}$ & $\begin{array}{l}\text { 30 dari 32 siswa } \\
\text { tuntas }\end{array}$ & $\begin{array}{l}\text { 2 siswa belum } \\
\text { tuntas }\end{array}$ \\
\hline
\end{tabular}

\section{Data Hasil Pengamatan}

Penilaian proses menjadi salah satu bahan penilaian autentik bagi guru. Penilaian proses didasarkan pada indikator pencapaian kompetensi yang belum tertera pada penilaian hasil serta penilaian sikap yang dikembangkan selama pembelajaran. Proses peserta didik menulis teks narasi mulai dari melakukan survei bacaan sampai dengan menyajikan karyanya. Indikator atau rubrik penilaiannya adalah sebagai berikut.

Tabel 4.4 Ceklis (V) Penilaian Proses

Nama Peserta Didik :

No :

\begin{tabular}{|c|c|c|c|c|}
\hline No & Aspek/Kegiatan & Indikator & $\mathrm{Ya} / \mathrm{T}$ & $\begin{array}{l}\text { Ket } \\
(1 / 0)\end{array}$ \\
\hline 1. & Survei bacaan & $\begin{array}{l}\text { - Membaca teks } \\
\text { seksama dengan } \\
\text { pertanyaannya }\end{array}$ & & \\
\hline 2. & Hadirkan Objek & $\begin{array}{l}\text { - Menentukan objek/tema dan } \\
\text { menyusun kerangka }\end{array}$ & & \\
\hline 3. & Wujudkan & $\begin{array}{l}\text { - Membuat kalimat showing, } \\
\text { dialog, dan first line yang } \\
\text { menarik }\end{array}$ & & \\
\hline 4. & Imajinasikan & 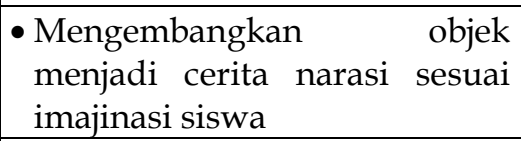 & & \\
\hline 5. & Naskah narasi & $\begin{array}{l}\text { - Menyusun teks narasi lengkap } \\
\text { sesuai struktur dan unsur }\end{array}$ & & \\
\hline
\end{tabular}




\begin{tabular}{|c|l|l|l|l|}
\hline & & kebahasaannya & & \\
\hline 6. & Gaungkan & $\begin{array}{l}\bullet \text { Mempresentasikan hasil karya } \\
\text { dengan } \\
\text { semangat/mengumpulkan file } \\
\text { naskah narasi }\end{array}$ & & \\
& & & \\
\hline
\end{tabular}

Berdasarkan pengamatan mengenai tahapan pembelajaran tersebut, hampir seluruh siswa telah melaksanakan tahap-tahap pembelajaran dan hanya ada dua peserta didik di kelas 7J dan tiga siswa di kelas 7I yang agak kurang antusias dikarenakan faktor internal mereka karena pada dasarnya mereka tidak kerasan dipondok sehingga mempengaruhi motivasi dalam belajarnya. Adapun untuk siswa kelas IX tidak ada permasalahan pada prosesnya. Akan tetapi, masih ada dua siswa yang kesulitan dalam menggali idenya dikarenakan ia mengaku tidak suka membaca novel ataupun buku-buku fiksi lainnya.

\section{Analisis Data Hasil Aplikasi Praktis}

Data hasil aplikasi praktis pembelajaran dengan Teknik SHOWING (Berbantuan Multimedia Kreatif) untuk Meningkatkan Keterampilan Teks Narasi analisisnya adalah sebagai berikut.

Pertama, hasil pengamatan pembelajaran yang dilakukan guru dan kolaborator menunjukan bahwa 100\% pembelajaran terlaksana sesuai lembar pengamatan dengan indikator pengamatan kegiatan pendahuluan, inti, sampai penutup sesuai tabel 4.5 berikut ini.

\section{Tabel 4.5 Ceklis Kriteria Keterlaksaan KBM}

\begin{tabular}{|c|l|c|}
\hline No. & \multicolumn{1}{|c|}{ Kriteria Keterlaksanaan KBM } & $\begin{array}{c}\text { Ya/Tidak } \\
(\sqrt{ })\end{array}$ \\
\hline 1. & $\begin{array}{l}\text { Pendahuluan } \\
\text { 1. } \quad \text { Memotivasi siswa pada kegiatan apersepsi } \\
\end{array}$ & $\sqrt{ }$ \\
& $\begin{array}{l}\text { 2. } \quad \text { Siswa memahami karakteristik teks narasi melalui } \\
\text { tanya-jawab }\end{array}$ & $\sqrt{ }$ \\
& $\begin{array}{l}\text { 3. Membangun pengetahuan awal } \\
\text { 4. Menjelaskan KD, IPK, dan tujuan pembelajaran }\end{array}$ & $\sqrt{ }$ \\
\hline 2. & $\begin{array}{l}\text { Kegiatan Inti } \\
\text { 1. Siswa memahami ciri umum, struktur dan unsur } \\
\text { kebahasaan teks narasi }\end{array}$ & $\sqrt{ }$ \\
\hline
\end{tabular}




\begin{tabular}{|c|c|c|}
\hline & $\begin{array}{l}\text { 2. Menjelaskan langkah-langkah pembelajaran } \\
\text { 3. Mengorganisasikan siswa untuk belajar } \\
\text { 4. Membimbing siswa untuk memahami teknik } \\
\text { 5embelajaran } \\
\text { 5. Membimbing siswa untuk melatihkan keterampilan } \\
\text { berpikir } \\
\text { 6. Memanfaatkan media pembelajaran secara efektif } \\
\text { 7. Mengembangkan siswa untuk melatih menulis teks } \\
\text { narasi } \\
\text { 8. Siswa menyajikan teks narasi yang sudah ditulis } \\
\text { 9. Memberi pendampingan dan umpan balik }\end{array}$ & $\begin{array}{l}\sqrt{ } \\
\sqrt{ } \\
\sqrt{ }\end{array}$ \\
\hline 3. & $\begin{array}{l}\text { Penutup } \\
\text { 1. Guru menyimpulkan kegiatan atau hasil } \\
\text { pembelajaran } \\
\text { 2. Menjelaskan hal-hal yang sulit atau kurang dipahami } \\
\text { siswa } \\
\text { 3. Guru dan siswa merefleksikan hasil pembelajaran } \\
\text { 4. Guru memberi penghargaan pada siswa yang } \\
\text { kinerjanya bagus }\end{array}$ & $\begin{array}{l}\sqrt{ } \\
\sqrt{ }\end{array}$ \\
\hline
\end{tabular}

Berdasarkan tanggapan atau respon siswa terhadap pembelajaran Teknik SHOWING (Berbantuan Multimedia Kreatif) untuk Meningkatkan Keterampilan Teks Narasi sesuai tabel 3.9 di bawah ini didapatkan hasil 1) $100 \%$ mengaku menyukai teknik pembelajaran, memudahkan menulis teks narasi dan meningkatkan keterampilan menulis mereka; 2) 100\% buku kerja siswa mudah dipahami tetapi hanya 93\% (119/129 siswa) yang mengaku bahwa BKS mudah dikerjakan; 3) 100\% guru memberikan arahan dan pendampingan kelompok tetapi hanya 88\% (114/129 siswa) yang mengaku mendapat pendampingan individual; 4) hanya $77 \%$ (99/129) peserta didik merasa waktu pembelajaran mencukupi sehingga menganggap waktu pembelajarannya masih kurang; dan 5) sebanyak 93\% (119/129) menyatakan bahwa pembelajaran menyenangkan bagi mereka.

\section{Tabel 4.6 Tanggapan terhadap Teknik Pembelajaran}

Nama Siswa : No. :

\begin{tabular}{|c|l|c|c|}
\hline No & \multicolumn{1}{|c|}{ Aspek } & \multicolumn{1}{|c|}{ Ya/Tidak } & Ket \\
\hline 1. & $\begin{array}{l}\text { Saya menyukai teknik pembelajaran yang } \\
\text { dilakukan guru }\end{array}$ & $\sqrt{ }$ & $100 \%$ \\
\hline 2. & Teknik pembelajarannya memudahkan saya & $\sqrt{ }$ & $100 \%$ \\
\hline
\end{tabular}




\begin{tabular}{|c|l|c|c|}
\hline & dalam menyusun teks narasi & $\sqrt{ }$ & $100 \%$ \\
\hline 3. & $\begin{array}{l}\text { Teknik pembelajaran tersebut meningkatkan } \\
\text { keterampilan menulis saya }\end{array}$ & $\sqrt{ }$ & $100 \%$ \\
\hline 4. & Buku kerja siswa (BKS) mudah dipahami & $\sqrt{ }$ & $93 \%$ \\
\hline 5. & BKSnya mudah dikerjakan & $\sqrt{ }$ & $100 \%$ \\
\hline 6. & Guru memberikan arahan jelas & $\sqrt{ }$ & $88 \%$ \\
\hline 7. & Guru memberikan pendampingan kelompok & $\sqrt{ }$ & $88 \%$ \\
\hline 8. & Guru memberikan pendampingan individual & $\sqrt{ }$ & $77 \%$ \\
\hline 9. & $\begin{array}{l}\text { Waktu pembelajaran yang diberikan guru } \\
\text { mencukupi }\end{array}$ & $\sqrt{ }$ & $93 \%$ \\
\hline 10. & Pembelajarannya menyenangkan & & \\
\hline
\end{tabular}

\section{Pembahasan}

Menurut Keraf (2007: 136), narasi merupakan suatu bentuk wacana yang berusaha menggambarkan dengan sejelas-jelasnya kepada pembaca mengenai suatu peristiwa yang terjadi. Narasi berusaha menjawab sebuah pertanyaan apa konflik yang terjadi pada tokoh, dan bagagamana penulis mengeksekusi konflik tersebut. Bentuk karangan ini berusaha mengisahkan suatu kejadian atau peristiwa yang seolah-olah pembaca dapat melihat dan dapat mengalami peristiwa itu. Unsur yang penting dalam narasi ini adalah perbuatan atau tindakan dan rangkaian waktu peristiwa itu terjadi. Dengan demikian, narasi yang baik menurut penelitian ini adalah teks yang sesuai dengan indikator-indikator yang telah ditentukan dalam rubrik penilaian (ada 20 indikator sesuai tabel 3.1). Selain itu keberhasilan penelitian ini tidak ditentukan dari hasil pembelajran saja, melainkan proses pembelajaran juga merupakan penentu kesuksesannya. Proses pembelajran dapat diketahui berdasarkan hasil pengamatan, sedangkan hasil pembelajaran berdasarkan nilai hasil karya siswa.

Berdasarkan hasil pengamatan tersebut ada beberapa hal yang perlu dievaluasi, antara lain 1) masih ada siswa yang kurang aktif meskipun prosentasenya hanya sedikit (7\%); akan tetapi belajar adalah hak setiap individu sehingga perlu diupayakan agar seluruh peserta didik aktif, 2) masih ada siswa yang perlu pendampingan khusus karena berdasarkan tanggapan mereka ada yang merasa masih kesulitan dalam 
menyelesaikan BKS dan belum mendapat pendampingan individual yang memadai, 3) perlu adanya penambahan waktu untuk PBM karena 23\% peserta didik yang mengaku waktunya kurang mencukupi sehingga ada tugas yang dikerjakan di luar PBM seperti menulis teks narasi mandiri.

Hasil pembelajaran dengan Teknik SHOWING (Berbantuan Multimedia Kreatif) untuk Meningkatkan Keterampilan Teks Narasi untuk menyajikan teks narasi secara kelompok sesuai tabel 3.5 ada satu kelompok dari 30 kelompok yang belum tuntas dengan rata-rata nilai 85, sedangkan secara individual keberhasilan berdasarkan kriteria ketuntasan minimalnya mencapai 95\% karena ada tujuh siswa yang perolehan nilainya kurang dari KKM. Namun demikian, nilai rata-rata individu mencapai 87,5 .

Tabel 4.7 Hasil Pembelajaran dengan Teknik SHOWING (Berbantuan Multimedia Kreatif) untuk Meningkatkan Keterampilan Teks Narasi

\begin{tabular}{|c|c|c|c|}
\hline No & \multicolumn{1}{|c|}{ Jenis Pembelajaran } & Hasil & Prosentase \\
\hline 1. & Kelompok (cooperative learning) & $\begin{array}{c}29 / 30 \\
\text { kelompok tuntas }\end{array}$ & $97 \%$ \\
\hline 2. & Mandiri/Individual & $\begin{array}{c}122 \text { tuntas } \\
7 \text { belum tuntas }\end{array}$ & $95 \%$ \\
\hline
\end{tabular}

Berdasarkan tabel 4.7, keberhasilan pembelajaran dengan Teknik SHOWING (Berbantuan Multimedia Kreatif) untuk Meningkatkan Keterampilan Teks Narasi, secara kelompok mencapai 97\% dan secara individual mencapai $95 \%$. Analisis dua puluh indikator penilaian pembelajaran Teknik SHOWING (Berbantuan Multimedia Kreatif) untuk Meningkatkan Keterampilan Teks Narasi adalah sebagai berikut.

Indikator 1) Pemilihan tema: meliputi aktual dan secara psikologis sesuai dengan usia; satu tema dan koherensif; tidak menyinggung suku, ras, dan agama; dan mengandung nilai moral, secara keseluruhan hasil karya siswa memenuhi indikator-indikator tersebut. Ada beberapa karya siswa (20@n siswa) yang sebenarnya dari segi usia mereka kurang sesuai, misalnya mereka menceritakan remaja usia SMA atau perguruan tinggi. 
Akan tetapi, hal tersebut tidak dapat dikategorikan tidak sesuai karena kreativitas siswa tidak boleh dibatasi bahkan harus dikembangkan karena dari segi tema masih sesuai bahkan idenya lebih bagus.

Indikator 2) Pengaluran/struktur teks: terdapat 4 struktur teks, membuat konflik yang tajam, menyampaikan lebih dari satu konflik, membuat akhiran mengejutkan, memberikan gambaran peristiwa dengan jelas (showing), memberi pesan yang mudah diterima; dari segi struktur teks sebagian besar telah memenuhi, hanya ada tiga siswa yang struktur teksnya belum tuntas. Ketiga siswa ini teks narasi belum tuntas dari segi struktur sehingga perlu remedial untuk menyelesaikan tugasnya. Setelah dilakukan remedial, hasilnya lebih baik. Kelemahan siswa dalam pengaluran adalah pada pembuatan konflik yang tajam, lebih dari satu konflik, akhiran mengejutkan, dan gambaran yang jelas. Berikut contoh karya siswa.

"Si James dan Melia pergi ke danau untuk berfoto-foto, sesudah foto-foto si James mengajak untuk berfoto di pohon yang sangat besar itu tetapi Melia tidak mau karena ia takut apa yang diucapkan nenek-nenek, tetapi si James memaksa untuk berfoto di pohon tersebut, akhirnya Melia pun mau berfoto, sesudah berfoto mereka pun pulang. Suatu hari si James ingin pergi ke mal untuk membeli-beli, sesudah membeli-beli si Jamespun pulang. Pada saat di tengah-tengah jalan si James kecelakan lalu meninggal dunia. Pada saat mendengar James meninggal Melia pun teringat mitos mengenai pohon besar itu...(7J12.2)"

Kutipan karya siswa tersebut masih belum mampu memberikan konflik yang tajam bahkan terkesan terlalu datar. Selain itu konflik yang diceritakan hanya satu konflik dan akhirannya 'dieksekusi' dengan tergesa-gesa. Upaya perbaikannya dengan memberikan pelatihan berulang untuk menyusun ide menjadi kalimat yang menarik dan 'mengalir'. Padahal siswa tersebut sudah diberi pembimbingan untuk membuat kalimat 'showing', tetapi dengan alasan terburu tenggat waktu siswa ini menulis narasi individunya terkesan tergesa-gesa.

Menghadapi masalah tersebut, guru perlu mengevaluasi pola pembimbingan pembuatan kalimat showing agar tepat sasaran. Ketika 
objek yang perlu dibuatkan kalimat 'showing' berbeda dengan objek yang menjadi tulisan siswa, hal ini menjadi tantangan tersendiri bagi siswa. Hasilnya masih ada beberapa siswa yang belum mampu merumuskan kalimat yang tepat untuk menggambarkan objeknya. Untuk itu, pembimbingan yang tepat sebaiknya pembimbingan yang langsung pada sasaran yang menjadi objek tulisan siswa.

Indikator 3) Kreativitas ide: ide diekspresikan dengan jelas, peristiwa dikembangkan secara rinci dan unik, pilihan kata menarik, dialog menarik/tidak monoton, secara keseluruhan sudah baik setelah ada pelatihan pembuatan kalimat showing. Namun demikian, masih ada dua siswa di kelas 7J yang memulai cerita narasinya dengan pilihan kata yang monoton yakni "Pada suatu hari..." dan penggunaan kata hubung yang monoton (7J15; 7J27). Meskipun sudah ada pelatihan pembuatan showing masih ada siswa yang nilai indikator kreativitas ide belum tuntas.

Indikator 4) Kebahasaan: menggunakan diksi bahasa Indonesia semiformal/formal, menggunakan bahasa yang komunikatif, menggunakan kalimat emotif/empati/simpati, menggunakan kalimat yang jelas dan runtut; secara umum untuk indikator keempat ini hasil siswa sudah baik. Akan tetapi, masih ada beberapa siswa yang kurang mampu menggunakan kalimat emotif/empati/simpati dikarenakan 'eksekusi' konflik yang tergesa-gesa seperti pada contoh kasus siswa pada indikator dua di atas. Untuk permasalahan seperti ini, guru perlu membimbing siswa secara individual khususnya penggunaan diksi, kalimat efektif, dan kalimat emotif.

Indikator 5) Penggunaan ejaan dan tanda baca: tidak ada kesalahan atau kesalahan ejaan $\leq 5$, tidak ada kesalahan atau kesalahan tanda baca $\leq 5$; untuk indikator ini masih banyak siswa yang menjadi subjek penelitian ini hasil karyanya belum memenuhi karena hampir 50\% kesalahannya ejaan dan tanda bacanya $\leq 5$. Penyebabnya adalah adanya kesalahan ketik dan ketidakpahaman aturan penggunaan ejaan dan tanda baca. Perlakuan atau treatment untuk indikator lima ini adalah dengan 
membelajarkan aturan penggunaan ejaan dan tanda baca yang mengacu pada PUEBI (pedoman umum ejaan bahasa Indonesia).

\section{Penutup}

Karya inovasi Teknik SHOWING (Berbantuan Multimedia Kreatif) untuk Meningkatkan Keterampilan Teks Narasi di SMPN 3 Peterongan rancangan penelitiannya menggunakan kerangka pengembangan model 4D (define, design, develop, dan dessiminate) ditambah tahap evaluate. Teks Narasi yang menjadi materi penelitian ini adalah narasi fiksi yang mencakup teks fantasi, fabel, cerpen, dan cerita inspiratif. Subjek penelitiannya kelas 7I, 7J, 9D, dan 9E. Multimedia yang digunakan selain bahan ajar cetak adalah tayangan PPT, videoscribe, dan powtoon.

Multimedia dalam karya inovasi ini digunakan untuk memberikan stimulus, memudahkan siswa memahami konsep, melakukan kegiatan-kegiatan pembelajaran, dan mempercepat mereka untuk menyelesaikan tugasnya. Setiap jenis teks memanfaatkan multimedia yang berbeda sesuai rancangan pembelajaran.

Hasil pengembangan karya inovasi pembelajaran ini menunjukan keberhasilan baik secara kelompok maupun secara mandiri. Secara kelompok keberhasilan mencapai 97\% sedangkan secara mandiri mencapai 95\%. Selain itu, pengembangan karya inovasi ini telah didiseminasikan di MGPM Bahasa Indonesia SMP Jombang untuk Wilayah Timur.

\section{Ucapan Terimakasih}

Terima kasih saya sampaikan kepada pak Jack Parmin, Dr Eva Eri Dia, serta teman-teman validator dan kolaborator lainnya. Terima kasih juga pada orangtua saya di surga yang telah mendidik saya dengan nilainilai kebaikannya. Terima kasih juga pada teman-teman sejawat di MGMP Bahasa Indonesia SMP se-Jombang. Berkaryalah terus karena dengan karya kita dikenang. 


\section{Daftar Referensi}

Dalman . 2015. Menulis Karya Ilmiah. Depok: Rajagrafindo Persada.

Eriyanto. 2015. Analisis Naratif: Dasar-dasar dan Penerapannya. Jakarta: Prenada Media.

Gina, Asifa Miftakhul, dkk. 2017. Meningkatkan Keterampilan Menulis Karangan Narasi Melalui Model PWIM (Picture Word Inductive Model) Siswa Kelas IV-B SD Negeri Ketib Kecamatan Sumedang Utara Kabupaten Sumedang. Jurnal Pena Ilmiah Vol.2 No.1, 891900.

Keraf, Gorys. 2007. Argumentasi dan Narasi. Jakarta: Gramedia Pustaka.

Lestari, Ika. 2013. Pengembangan Bahan Ajar Berbasis Kompetensi. Padang: Akademia.

Slavin, Robert E, 2015 (cet ke-15). Cooperative Learning (Penerjemah: Narulito Yusron). Bandung: Nusa Media.

Stanton, Robert. 1965. An Introduction to Fiction. Washington: University of Washington.

Tantikasari, Betty Suci, dkk. 2017. Keefektivan kemampuan Menulis Karangan Narasi melalui Puzzle Gambar Berseri di SDN Jiken Blora. Jurnal Dinamika Pendidikan Vol XXI No.2 November 2017, 83--97.

Thiagarajan, S. Semmel, dkk. 1974. Instuctional Development for Training Teachers of Exceptional Children. Bloomimgton: Indiana University.

Wahyuningrum, Iis Dyah. 2016. Meningkatkan Kemampuan Menulis Paragraf Narasi melalui Media Buku Harian pada Siswa Kelas VII

MTsN Saradan. Widyabastra Vol.4 No.2, 2016, 165-182.

https://www.powtoon.com diakses pada 12 Juli 2018. 